\title{
Espiritualidade em tempos de pandemia: sobre a oração na hora da crise
}

\author{
Spirituality in pandemic times: \\ prayer in the time of crisis
}

Ceci Maria Costa Baptista Mariani

Breno Martins Campos

\section{Resumo}

O poder da oração na hora da crise é importante questão, imposta desde sempre à história das religiões - ainda mais agora, em tempos de crise global pela disseminação da Covid-19. A história das religiões demonstra que, de modo geral, não é possível desatrelar a saúde física da espiritual, nem tratar da salvação da alma sem a consideração da saúde integral da pessoa. Assim, nosso artigo tem como objetivo geral subsidiar a reflexão sobre a potência da oração em tempos de crise. Por meio de pesquisa teológica, bibliográfica e exploratória, compreendemos que o livro de Jó é exemplar para a reflexão da relação entre fé e cura, e também sobre a força da oração. Todavia, a narrativa do drama de Jó não dá solução definitiva ao problema do mal, nem sugere recursos mágicos para alívio do sofrimento humano. Na sequência, oferecemos modelos e experiências de oração em tempos vividos no vale de sombra e de morte (S1 23), de como orar segundo o coração de Deus, a mente de Cristo e o exemplo da mística de São João da Cruz; e, por fim, de como orar em tempos pandêmicos de acordo com as exortações do Papa Francisco.

Palavras-chave: Oração. Pandemia. Espiritualidade. Saúde e salvação. Cura. 


\begin{abstract}
The power of prayer in the face of a major crisis is an important issue that has been discussed in the past months due to the planetary reach of the trouble caused by the Coronavirus outbreak. Generally, in the history of religions, it is well known that physical and spiritual health can never be untied. Similarly, it does not seem possible to work on the salvation of one's soul without considering one's health. Therefore, this article aims to provide a basis for reflecting on the power of prayer in times of crisis. Through theological bibliographical and exploratory research, we understand that the book of Job is exemplary regarding the reflection on the relationship between faith and cure and the power of prayer. Nevertheless, the drama in Job's narrative does not provide a solution to the problem of the challenges of evil, neither suggests magical solutions to unburden the human suffering. Then, this article offers prayer models and experiences in times lived through the valley of the shadow of death (Psalm 23), accordingly to God's heart, Christ's mind, and Saint John of the Cross' mystical experience, and finally, how to pray in times of pandemic according to Pope Francis' exhortations.
\end{abstract}

Keywords: Prayer. Pandemic. Spirituality. Health and salvation. Cure.

\title{
Introdução
}

Segundo dados do Ministério da Saúde brasileiro, ${ }^{1}$ o novo agente do coronavírus (nCoV-2019) foi descoberto em dezembro de 2019 após casos de infecções respiratórias registrados na China. No Brasil, segundo a linha do tempo construída pelo Ministério da Saúde, o primeiro caso foi confirmado aos 26 de fevereiro de 2020. Em poucos meses, a pandemia já estava instaurada, atingindo muitos países. "A cruel pedagogia do vírus", para ficarmos com a expressão de Boaventura de Sousa Santos, ${ }^{2}$ tem ensinado lições importantes e revelado que estamos diante de um possível

\footnotetext{
${ }^{1}$ BRASIL, Ministério da Saúde, Resposta nacional e internacional de enfrentamento ao novo coronavírus.

${ }^{2}$ SANTOS, B. S., A cruel pedagogia do vírus.
} 
esgotamento de certo modo de vida, assim como tem nos colocado frente às exigências da criação de novas formas de existir. Quem sabe, possamos aprender a fazer "um bom uso do fim de um mundo", como propõe Patrick Viveret $^{3}$ - e assim consigamos também inventar uma nova relação com a riqueza e com o poder (o que é necessário, mas não suficiente), pois precisamos, ainda, de um novo conceito que inclua abertura e diálogo entre as tradições espirituais e religiosas.

Sem dúvida, portanto, a espiritualidade também é pauta importante nestes tempos pandêmicos. Faustino Teixeira, teólogo brasileiro que é referência importante para o tema do diálogo inter-religioso, finaliza o artigo "Malhas da hospitalidade" com um tópico em que admite ser o grande desafio espiritual do século XXI uma nova reverência à vida: é preciso somar forças, ele afirma, "e unir os corações numa comunidade global sintonizada com o cuidado da Terra e a afirmação da dignidade de todos". ${ }^{4}$ São desafios globais e urgentes, cuja realização passa, por óbvio, pelo ecumenismo e diálogo inter-religioso - e pelo diálogo das religiões com os ateísmos. Neste sentido, nunca será demais a referência a Hans Küng e seu projeto de ética mundial: "Não haverá sobrevivência sem uma ética mundial. Não haverá paz no mundo sem paz entre as religiões. E sem paz entre as religiões não haverá diálogo entre as religiões". 5

Colocando-se em diálogo com uma trajetória em andamento - e em face da emergência advinda da Covid-19, que é de variadas naturezas -, este artigo foi motivado por algumas das perguntas levantadas e dirigidas à Teologia em nosso cotidiano (e às Ciências da Religião, por que não?). Diante do sofrimento dos atingidos pela dor e pela morte (milhares e milhares de pessoas), perguntamo-nos como poderia a fé ajudar ou, ainda, se a fé seria uma tábua de salvação legítima em situações de desespero.

Tem razão o compositor Gilberto Gil: “Andá com fé eu vou / Que a fé não costuma faiá". ${ }^{6}$ Mas, também ele, mantém uma dúvida no ar: "A fé tá na manhã / A fé tá no anoitecer / Ô-ô / No calor do verão / A fé tá viva e sã / A fé também tá pra morrer / Ô-ô / Triste na solidão". Também a fé pode morrer, também ela "tá pra morrer". Então, impõe-se novamente a pergunta: qual o estatuto da fé em tempos de pandemia? E outras: qual o

\footnotetext{
${ }^{3}$ VIVERET, P., Sobre o bom uso do fim de um mundo, p. 25-39.

${ }^{4}$ TEIXEIRA, F., Malhas da hospitalidade, p. 34.

${ }^{5}$ KÜNG, H., Projeto de ética mundial, p. 7.

${ }^{6}$ GILBERTO GIL, Andar com fé.
} 
lugar da fé no mundo que virá? quais credos e confissões recitarão os filhos e as filhas de nossa geração? em que apostarão suas vidas as pessoas que ainda estão por vir?

Em meio a tantas questões, surgem interpretações teológicas "tagarelas e barulhentas", como aponta João Décio Passos, "promessas de salvação da contaminação, soluções mágicas por meio de rituais e orações, discursos sobre origens sobrenaturais da pandemia, luta entre o bem e o mal". ${ }^{7}$ Em nosso país, os ruídos desse tipo de teologia se juntam às emanações planas e rasas de interpretações teológico-políticas que nos assolam. Diante da crise, queremos discutir não uma saída alienada - que apela ao sobrenatural com os olhos fechados e a cabeça no céu -, mas outra, talvez mais desafiadora, que se apoia no enfrentamento do silêncio de Deus - uma forma de vida mística, mas com os olhos abertos e os pés no chão.

Na música "Perfeição" (Legião Urbana), ${ }^{8}$ podemos ouvir: "Quando a esperança está dispersa / Só a verdade me liberta”. Como na letra da canção, este artigo trata da verdade que liberta, ou seja, da alétheia que desvela e exige de nós uma decisão vivencial - simplesmente não dá para celebrar nosso governo e as epidemias, nem comemorar os mortos por falta de hospitais. Como a letra de uma música, que integra um disco ("O descobrimento do Brasil") lançado em 1993, pode ser, assim, tão atual? Na dureza e crueldade da vida real, quando até a fé pode faiá e a esperança está dispersa, eis que "O amor tem sempre a porta aberta / E vem chegando a primavera / Nosso futuro recomeça" (Legião Urbana). Futuro que não pode ser nostalgia de um passado idealizado, mas ressurreição.

Por conseguinte, tem este artigo o objetivo de subsidiar a reflexão sobre a oração (e seu poder) nestes meses de crise global - mas também subjetiva - provocada pela disseminação da Covid-19. A problemática que estamos a propor está localizada na encruzilhada da oração (a voz do ser humano) com o silêncio de Deus, a mesma que um dia se impôs nos caminhos trilhados por Jó, pelo salmista Davi, por Jesus Cristo e por São João da Cruz - e por onde caminha agora o Papa Francisco.

\footnotetext{
${ }^{7}$ PASSOS, J. D., O vírus vira mundo, p. 135.

${ }^{8}$ LEGIÃO URBANA, Perfeição.
} 


\section{Oração e Sabedoria no livro de Jó}

A relação entre fé e cura é bem antiga. Se mirarmos panoramicamente a história das religiões, vamos encontrar muitas tradições e crenças em que não é possível desatrelar a saúde física da espiritual, assim como não se pode trabalhar a salvação da alma (nos casos em que sua existência é concebível) sem considerar a saúde integral do ser humano. No mundo antigo, em geral, enfermidade é desordem, possessão e também castigo imposto pelos deuses aos pecadores. Na Mesopotâmia, por exemplo, médicos recorriam a métodos divinatórios para descobrir o pecado cometido pelo doente, e para isso inspecionavam as entranhas de animais abatidos para obter conhecimento e apaziguar os deuses. Dentre os judeus antigos, doenças podiam ser uma maneira pela qual Deus castigava pecadores e inimigos do povo eleito.

Em nossa sociedade (secularizada, é bom reconhecermos), já não faz mais sentido associar doenças a castigo de Deus - a não ser em pequenos grupos de religiosos fanáticos, que, infelizmente, fazem muito ruído (porque sabem usar as redes sociais como poucos) e, portanto, são ouvidos por muita gente -, em contrapartida, encontramos pesquisas empíricas que buscam apontar, por recursos da ciência, a influência da espiritualidade na saúde, por exemplo, o poder de cura da oração, fé, crença. São muitos os exemplos, mas, sem que entremos em detalhes de um ou outro, concordamos com Leo Pessini ao observar que esses estudos não mostram resultados claros e, muitas vezes, levantam questões que não podem ser respondidas. ${ }^{9}$ As tentativas de mensurar os efeitos da fé e da espiritualidade na saúde servem mais para levar a resultados imprecisos e revelar que métodos científicos dificilmente poderão responder questões de ordem existencial.

O desafiador livro de Jó - típico do que é o humano em suas complexas relações interiores e interpessoais - vem a nosso auxílio na reflexão quanto à relação entre fé e cura, e também na compreensão da força possível da oração. A redação final da obra literária e testemunho de fé é provavelmente do período pós-exílico na história de Israel, em alguma pequena província da Judéia. ${ }^{10}$ Trata-se de uma obra de sabedoria de alcance universal (um clássico, na acepção do termo), pois trata de dilemas que não têm data nem local - ainda que, primeiramente, tenham respondido questões datadas e

\footnotetext{
${ }^{9}$ PESSINI, L., A espiritualidade interpretada pelas ciências e pela saúde, p. 187-195.

${ }^{10}$ MACKENZIE, R., Fundo cultural e religioso do livro de Jó, p. 5-11.
} 
localizadas. Contribuindo para a reflexão da relação do ser humano com Deus, o texto se constitui num drama sobre a fé em Deus em meio ao sofrimento. Contra Satã (o acusador), cujo discurso acusa a fé de Jó de ser interesseira e seu amor a Deus de estar ligado à saúde e prosperidade, a narrativa apresenta a convicção de Javé de que a fé pode estar apoiada na gratuidade de forma genuína - e que este é o caso de Jó. ${ }^{11} \mathrm{O}$ livro é uma bela narrativa sapiencial sobre o que sofrimento representa para a fé. O livro de Jó é o drama de nós todos ${ }^{12}$ - de quase todos, é bem verdade, pois há pessoas incapazes de sentir e cultivar a empatia.

Tendo de enfrentar toda a sorte de provações - perda de filhos e bens, e uma doença maligna e invasiva -, Jó reage contra a concepção tradicional de que o mal e o sofrimento são castigos divinos por pecado cometido. Depois de longa discussão com seus amigos, que defendem a tradição da culpa e a teologia da retribuição pelo pecado, Jó se revolta. O drama se converte numa espécie de júri simulado de um processo que visa a um acerto de contas entre Deus e a humanidade. ${ }^{13} \mathrm{Na}$ verdade, para chegarmos a uma compreensão justa do sofrimento, o livro de Jó afirma que a imagem de Deus não pode ser aquela de alguém que domina pelo poder ou pelo terror - concepção fantasiosa que se faz bem presente em boa parte das interpretações do sofrimento humano.

O texto sapiencial adverte, ainda, que o ser humano deve buscar o sentido da doença para além dos limites de uma teologia da retribuição a afirmar que o justo é recompensado com bem-estar e saúde, ao passo que o pecador é castigado com pobreza e doença. A fé em Deus e a convicção da inocência levam Jó a clamar por Deus - o Sagrado que se achega ao humano para o colocar diante da grandiosidade da criação, das maravilhas do universo com seus mistérios administrados pela Sabedoria. Assim, Jó sai de seu próprio sofrimento e se insere numa realidade maior, na qual tudo adquire sentido salvífico, até mesmo, ou especialmente, o sofrimento do inocente.

A permanência de Jó na fé significa, portanto, a busca de sentido do sofrimento num contexto mais amplo de busca pela compreensão do sentido da vida. "Só por ouvir dizer, te conhecia; mas agora, viram-te meus olhos" (Jó 42,6). Permanecer na fé, a despeito dos vales de sombra e de morte que estamos a atravessar: eis a lição existencial do livro de Jó.

\footnotetext{
${ }^{11}$ GUTIÉRREZ, G., O Deus da vida.

${ }^{12}$ MESTERS, C., Deus, onde estás?

${ }^{13}$ MESTERS, C., Deus, onde estás?
} 


\section{Oração em tempos sombrios (SI 23)}

Atribuído tradicionalmente a Davi, o S1 23 ("O senhor é meu pastor...") - um dos mais conhecidos, lidos e rezados de todo o saltério - pode ser classificado como um salmo de confiança individual, mas não nos parece heresia passível de excomunhão pensarmos nas palavras do salmista como uma oração de confiança coletiva. Pode ser até fácil confiar em Deus e uns nos outros, em tempos de vida, saúde e prosperidade, em contrapartida, perguntamos: e quando se impõe o "vale de sombra e de morte" $(\mathrm{Sl} 23,4)$ em nossas vidas? E quando se nos impõem tempos pandêmicos? Como confiar em Deus e no outro em tempos sombrios?

Deixamos aos especialistas as discussões quanto ao Sitz im Leben do S1 23, e vamos considerá-lo como uma espécie de obra de arte, ou seja, uma peça literária, um poema, enfim, uma oração - para permitir que ele nos seja luz que vem do passado a iluminar nosso presente. Embora nossa reflexão se encontre dentro da tradição cristã, ela pretende ser mais ampla, pois a condição humana nos une a todos, como irmãos - maior e mais forte é o que nos une diante daquilo que pode nos separar. Transformemos, portanto, o Sl 23 numa oração de confiança coletiva: o Senhor é nosso pastor e nada nos falta. Mas não falta - justamente - porque somos comunidade, uma imensa coletividade de pessoas de boa vontade (religiosas ou não) que estão espalhadas por todo o mundo: perdoamos as dívidas e ofensas uns dos outros, porque também fomos e somos perdoados. A vida é graça, é gratuidade.

É certo que em tempos sombrios mais pessoas perguntam por Deus e se perguntam a respeito do silêncio de Deus. Mas o que ele pode fazer, de fato? Não sabemos, ao certo: não seria demasiado falar em nome de Deus? É melhor tratarmos do que nós podemos fazer. $\mathrm{O}$ bom pastor conduz seu povo para pastagens verdejantes e de boa água. Trata-se de linguagem figurada, simbólica? Sim, mas do ponto de vista empírico (concreto) o planeta grita, a Terra grita - e, em meio à dor da criação, as pessoas mais pobres são as mais diretamente afetadas pelos sofrimentos do mundo.

Como pessoas pastoreadas por Deus e pastoras umas das outras, efetivamente, para onde estamos conduzindo nossas vidas e, mais importante, as vidas que virão depois de nós? Em que "verdes pastagens" (S1 23,2), em sentido figurado, estamos nos deitando, se hoje as pastagens, em sentido literal, não são mais para as pessoas, mas para o gado? A que "águas do repouso" (S1 23,2), em sentido figurado, o mundo se dirige, se nem sequer há água potável, em sentido 
literal, para todos os seres humanos que habitam o planeta? Que diremos, então, das vacinas contra a Covid-19? Se a nós interessa, de fato, que nada nos falte, então, temos de cuidar da Amazônia, do Pantanal, dos manguezais, das restingas, do quintal de nossa casa e do vaso de nossa sala. Não podemos permitir que passe a boiada (nos mais variados sentidos que guarda esta expressão).

Por conseguinte, não nos parece o momento apropriado de celebrarmos a mesa farta e o cálice transbordante num período histórico de tanta escassez e morte - muito menos se a intenção for alguma espécie de revanchismo contra o outro. Enquanto uma pessoa passar fome no mundo, toda a humanidade estará faminta. Mas se hoje são milhões e milhões de pessoas que passam fome, então, toda a humanidade deveria estar envergonhada. Não é sintomático que o prêmio Nobel da paz de 2020 tenha sido conferido ao "Programa Mundial de Alimentos" (da ONU)? A hora é de misericórdia, hospitalidade e comensalidade. Não pode haver paz se o copo de um transborda porque o do outro está vazio.

A maior tentação a que estamos submetidos em nosso tempo não é a do medo - uma vez que todos estamos com medo, uns mais, outros menos. A maior tentação a que estamos submetidos é a da indiferença em relação ao outro. A maior tentação é a de fazermos coro com o cinismo da resposta de Caim à pergunta de Deus após o assassínio de Abel. "O Senhor disse a Caim: 'Onde está o teu irmão Abel?' 'Não sei, respondeu ele: Sou eu o guarda de meu irmão?"” (Gn 4,9). Em momentos de crise aguda em nossa condição humana, precisamos entender como ouvir a voz de Deus, pois a quebra do silêncio divino pode ser de conforto (consolação), mas também de confronto (contestação). Somos irmãos uns dos outros, responsáveis uns pelos outros, de um modo diferente em nossos dias, é bem verdade, pois com restrições, distanciamento social, isolamento, quarentena - mas nenhum vale de sombra e de morte é permissão para a banalização da morte.

É abominável a lógica de que se todos vamos morrer, então, e daí que estejam caindo pessoas ao nosso lado? Que nossas mãos nunca sejam símbolos de instrumentos de morte, mas que nelas estejam os instrumentos de pastoreio (o bastão e o cajado) para a proteção do nosso próximo e a construção da paz. Quem é mesmo o nosso próximo? São todas as pessoas que estão em nosso caminho, lembremo-nos da parábola do samaritano (Lc 10,25-37). É preciso que caminhemos, em atitude mística no seguimento de Jesus de Nazaré, com os pés no chão e de olhos bem abertos. 


\section{Oração "de olhos abertos" segundo o espírito de Jesus}

No contexto da mística de olhos abertos, as pessoas que oram segundo o espírito de Jesus (em consonância com a mente de Cristo), afirma Johann Baptist Metz, "não podem orar de costas para o 'outro' que sofre". ${ }^{14}$ A empatia humana exigida pela oração exige que todos rezemos com os pobres e com os que sofrem, e que busquemos, com eles, descobrir o rosto paterno e materno de Deus, em sua atuação amorosa e libertadora. A atividade de cura sempre foi parte integrante do ministério de Jesus, no entanto, não apelava ele a uma intervenção milagrosa de Deus, mas a uma mudança de comportamento, que levasse a uma vida mais digna e segura. Jesus sempre soube vincular o poder de cura ao núcleo de sua mensagem, enxergava na cura realizada pela fé a irrupção de um novo mundo. As narrativas evangélicas não falam de Jesus como um homem a realizar feitos extraordinários para promoção de si mesmo, mas de alguém movido por grande compaixão pelos que sofrem: "em suma, a atividade taumatúrgica de Jesus tem por função ilustrar a 'boa nova' que ele anunciava simultaneamente por palavras". ${ }^{15}$

Jesus curava pela virtude da fé, ou seja, por uma energia que comunicava à fé do enfermo a força para o cuidado de si. Daí a expressão tão cara a Jesus: a tua fé te salvou. A fé invocada por Jesus, que tem poder de salvar e curar, não está depositada em um poder misterioso ou em conhecimentos ocultos. É fé em sentido amplo, fé no futuro, fé que tem um significado mais profundo do que é visto meramente por um olhar mais superficial. Essa fé no futuro é que tem o poder para desinstalar o doente paralisado em sua enfermidade pela autocomiseração ou exclusão social. O que Jesus pede das pessoas é confiança na bondade de Deus.

Jesus trabalha o coração do enfermo para que confie em Deus e se liberte de sentimentos obscuros de culpa e abandono por parte de Deus - que uma doença pode produzir. Ele cura pondo na vida do ser humano adoecido o perdão, a paz e a bênção de Deus. Ao enfermo, abre-se a possibilidade de viver com um coração novo e reconciliado com Deus. ${ }^{16}$ A saúde adquirida assim é mais do que cura, é salvação integral, é vida que se faz nova, renovada. A cura é sinal do reino de Deus já presente em nós, em nosso meio.

\footnotetext{
${ }^{14}$ METZ, J. B., Mística de olhos abertos, p. 126.

${ }^{15}$ MOINGT, J., Deus que vem ao homem, p. 300.

${ }^{16}$ PAGOLA, J. A., Jesus.
} 
Ainda sobre a mística de olhos abertos, Metz nos faz lembrar que é na oração que se encontra a história dos sofredores - aqueles que não constam nas histórias oficiais, que, em geral, são narrativas de feitos dos grandes e poderosos. ${ }^{17}$ Em lugar da hagiografia, com sua variegada construção de heróis e santidades, a história das religiões (e do cristianismo, em particular) deveria ser, antes de tudo, a história da oração, das vozes que se erguem aos céus diante das ameaças - ou mesmo de dentro do perigo. Porque um dos pontos de partida da oração é mesmo o sofrimento. $\mathrm{Na}$ história da humanidade, a voz do povo sem poder, mesmo com toda tentativa de silenciamento, pode ser captada na oração (preservada pelas diversas tradições religiosas).

$\mathrm{Na}$ tradição judaica revelada no Primeiro Testamento, afirma Metz, a linguagem da oração é fundamentalmente expressão do sofrimento e da crise, do lamento e da queixa, do grito: "é a linguagem da pergunta apaixonada a Deus, a linguagem daquela tensa esperança sofrida de que um dia Deus se justifique a si mesmo, diante da sombria história do sofrimento no mundo post Christum natum". ${ }^{18}$ A oração é o grito que vem das profundezas e busca a face oculta e silenciosa de Deus. A linguagem da oração não conhece proibição. Segundo o testemunho bíblico, na oração, podemos falar a Deus sobre sofrimento, dúvida, desejo, desespero, desamparo. A linguagem da oração "não reprime nem cerceia a linguagem dos sofredores, pelo contrário, ela a amplia até o imensurável e o indizível". ${ }^{19}$

Assim, superada a paralisia, o medo pode ser um adjuvante aos caminhos da oração, pois, na oração, o medo encontra condições de aceitação, não é reprimido, nem afastado, mas aceito e acolhido: "Medo, luto e tristeza podem ser o início da oração". ${ }^{20}$ A aceitação do medo na oração promove liberdade: "Justamente por meio do medo a oração pode libertar - como finalmente a oração libertou Jesus do medo e da tristeza, no Jardim das Oliveiras, deixando-o alerta e com o espírito claro". ${ }^{21}$ No momento mais trágico de sua vida, no ápice do cumprimento de sua missão, a oração de Jesus é um grito de desamparo dirigido a Deus. "Pai, se quiseres afastar de mim essa taça... No entanto, não se faça a minha vontade, mas a tua!"

\footnotetext{
${ }^{17}$ METZ, J. B., Mística de olhos abertos.

${ }^{18}$ METZ, J. B., Mística de olhos abertos, p. 121.

${ }^{19}$ METZ, J. B., Mística de olhos abertos, p. 123.

${ }^{20}$ METZ, J. B., Mística de olhos abertos, p. 124.

${ }^{21}$ METZ, J. B., Mística de olhos abertos, p. 124.
} 
(Lc 22,42). Em versão conhecida popularmente: "Pai, afasta de mim esse cálice". Fonte de inspiração para Gilberto Gil e Chico Buarque na letra da música "Cálice" [Cale-se]: "Como é difícil acordar calado / Se na calada da noite eu me dano / Quero lançar um grito desumano / Que é uma maneira de ser escutado / Esse silêncio todo me atordoa...". ${ }^{22}$

O símbolo da noite escura, tão bem expresso na poesia mística de São João da Cruz, ${ }^{23}$ serve bem para problematizar a paradoxal relação entre o sofrimento - "na calada da noite eu me dano" - e o poder da oração - "quero lançar um grito desumano". A noite escura na poesia de João da Cruz é a queixa poética da alma que sofre pela ausência divina, pelo silêncio de Deus em momento de grande desamparo. Mas, ao mesmo tempo, é momento de passagem, da descoberta de que Deus não está nos limites de nossos desejos, sempre a postos para atender nossos pedidos e suprir nossas necessidades. Na noite escura, descobrimos Deus na oferta do inesperado, do surpreendente. $\mathrm{Na}$ escuridão da noite, quando tudo parece fugir ao controle, emerge o momento privilegiado para realizarmos a saída de nós mesmos rumo ao encontro com Deus - em sua própria forma livre de amar.

A noite, para o místico, "aparece orientada a desprender o sujeito de si mesmo, a reorientar sua tendência a realizar-se sob a forma de autoafirmação e da constituição de si mesmo em centro de tudo, a libertá-lo da tentação de buscar sua salvação na posse e no espírito de propriedade". ${ }^{24}$ A noite proporciona o reconhecimento do próprio limite e o conhecimento do verdadeiro rosto misterioso de Deus, que se revela na transformação que opera em nós.

A noite abre possibilidade para uma nova forma de ser, de pensar e de querer. Depois de atravessada a noite, a alma (a Amada) é em Deus (no Amado) transformada: “Oh! noite que me guiaste, / Oh! noite mais amável que a alvorada; / Oh! noite que juntaste / Amado com amada, / Amada já no Amado transformada!". ${ }^{25}$ E a Igreja precisa se colocar em saída e serviço.

\footnotetext{
${ }^{22}$ CHICO BUARQUE, Cálice.

${ }^{23}$ JOÃO DA CRUZ, Obras completas.

${ }^{24}$ VELASCO, J. M., A experiência cristã de Deus, p. 221-222.

${ }^{25}$ JOÃO DA CRUZ, Noite Escura, n. 5.
} 


\section{Oração em tempos de pandemia}

Não há dúvidas de que estamos atravessando (todos e cada um) uma noite escura, como propõe o místico - e, de novo, em nosso país, a noite do "cale-se", como cantam os artistas. Em sentido oposto, no início de 2020, quando enfrentávamos os primeiros sinais dos efeitos da noite escura relacionada à disseminação global do novo coronavírus, o Papa Francisco conduziu um momento litúrgico - no adro da Basílica de São Pedro, aos 27 de março de 2020 - que vale a pena resgatarmos. De olhos abertos para a dramática situação de crise global, o Pontífice convocou os católicos para, unidos a ele em espírito, ouvirem a Palavra e elevarem a súplica a Deus por saúde, conforto e esperança. A Praça de São Pedro, em Roma, estava vazia (espécie de imagem-símbolo do que estávamos e ainda estamos vivendo em todo o mundo) em função das restrições impostas pela crise sanitária, e foi de lá e em tais condições que o Papa anunciou o Evangelho e concedeu a bênção Urbi et Orbi.

Em sua contundente homilia, Francisco interpretou a narrativa de $\mathrm{Mc}$ 4,35-41 (aquela do episódio conhecido como "a tempestade acalmada"), e refletiu sobre travessia, medo e fé - imagens e sentidos muito significativos para o momento atual. Ao atravessar o Lago de Tiberíades, chamado Mar da Galileia, os discípulos são surpreendidos por uma tempestade e se desesperam. Temerosos, reclamam angustiados a Jesus, que dormia tranquilamente na popa do barco: "Mestre, não te importa que pereçamos?" (Mc 4,38). Assim como os discípulos, compara Francisco, estamos também juntos, no mesmo barco, enfrentando águas turbulentas. A tempestade que ora atravessamos, o Papa atualiza e contextualiza a imagem, "desmascara a nossa vulnerabilidade e deixa a descoberto as falsas e supérfluas seguranças com que construímos os nossos programas, os nossos projetos, os nossos hábitos e prioridades". ${ }^{26}$

Os olhos abertos do Papa enxergam a responsabilidade humana que não tem ouvido os apelos de Deus em seu grande amor ao mundo: "não despertamos face a guerras e injustiças planetárias, não ouvimos o grito dos pobres e do nosso problema gravemente enfermo". ${ }^{27}$ Em contrapartida - e meio que a contragosto -, a tempestade que atravessamos descortina o fato

\footnotetext{
${ }^{26}$ FRANCISCO, PP., Momento extraordinário de oração em tempo de epidemia.

${ }^{27}$ FRANCISCO, PP., Momento extraordinário de oração em tempo de epidemia.
} 
inegável da "(abençoada) pertença comum a que não podemos subtrair: a pertença como irmãos". 28

Em resposta ao medo dos discípulos, Marcos 4,40 registra o apelo inconformado de Jesus: "Por que estais tão amedrontados? Ainda não tendes fé?". A nós, interpreta Francisco, ${ }^{29}$ Jesus lança um apelo à fé, a termos confiança no Senhor que ama o mundo. A pandemia não deve ser atravessada como castigo, como juízo de Deus - lembremo-nos de anatematizar esse tipo de Teologia -, mas como chamado à conversão e oportunidade de discernir e "decidir o que conta e o que passa, de separar o que é necessário daquilo que não o é". ${ }^{30} \mathrm{~A}$ força de Deus que vem a nós pela fé e pela oração, não como intervenção sobrenatural na realidade, mas como força do Espírito de Jesus, o crucificado-ressuscitado, que faz "resultar em bem tudo o que nos acontece", ${ }^{31}$ atua especialmente na teia de cuidado formado por pessoas comuns. Pessoas capazes de entregas corajosas e generosas, pois compreendem "que ninguém se salva sozinho". ${ }^{32}$

Em tempos de pandemia, nossa "tábua de salvação", segundo Francisco, ${ }^{33}$ é a cruz de Jesus, que nos inspira "a abandonar a nossa ânsia de onipotência e possessão, para dar espaço à criatividade que só o Espírito é capaz de suscitar". Abraçar a cruz neste momento "significa encontrar a coragem de abrir espaços onde todos possam sentir-se chamados e permitir novas formas de hospitalidade, de fraternidade e de solidariedade". ${ }^{34}$

Jesus não está mais conosco, em nosso barco - não, presencialmente, queremos dizer -, mas nossa vida, em resposta ao Evangelho e às exortações do Pontífice, tem de ser comunitária, ainda que, por ora, com distanciamento social e quarentena. Citando Milton Nascimento na canção "Travessia" (e, por apropriação e extrapolação teológicas, talvez alterando um pouco sua intencionalidade original), cujo título tem muitas relações com o episódio evangélico da tempestade acalmada, podemos cantar e orar: "Quando você foi embora / fez-se em noite em meu viver / forte eu sou mas não tem jeito / hoje eu tenho que chorar". 35

\footnotetext{
${ }^{28}$ FRANCISCO, PP., Momento extraordinário de oração em tempo de epidemia.

${ }^{29}$ FRANCISCO, PP., Momento extraordinário de oração em tempo de epidemia.

${ }^{30}$ FRANCISCO, PP., Momento extraordinário de oração em tempo de epidemia.

${ }^{31}$ FRANCISCO, PP., Momento extraordinário de oração em tempo de epidemia.

${ }^{32}$ FRANCISCO, PP., Momento extraordinário de oração em tempo de epidemia.

${ }^{33}$ FRANCISCO, PP., Momento extraordinário de oração em tempo de epidemia.

${ }^{34}$ FRANCISCO, PP., Momento extraordinário de oração em tempo de epidemia.

${ }^{35}$ MILTON NASCIMENTO, Travessia.
} 
O choro faz parte da oração, pode motivá-la - mas o medo pode ser também o começo da ação. Portanto - como fizemos com Sl 23, vamos também trocar a pessoa do discurso na letra de Milton Nascimento, do eu para o nós -, "não queremos mais a morte, temos muito que viver; já não sonhamos, hoje fazemos com nosso braço o nosso viver". Não que sejamos contra os sonhos, ao contrário, queremos sonhos e visões, mas, precisamos ir à luta. É preciso dizer aos poderes da morte: "Silêncio! Cala-te!" (Mc 4,39), como Jesus ordenou à tempestade.

\section{Conclusão}

A oração madura (no espírito de Jesus) implica, portanto, responsabilidade social e política. Antes de tudo, na contemporaneidade, ela é um ato de resistência contra a banalização e a falta de sentido da vida numa sociedade que valoriza fundamentalmente a satisfação de necessidades materiais. Mesmo em tempos nos quais a fé parece faiá, precisamos da oração.

Orar, afirma Metz, não é um jogo de perguntas e respostas, nem é tampouco uma troca: "Deus sempre fala, mas não responde, e quase nunca se repete! A oração torna nossas perguntas dúbias, nossos desejos estranhos, e revê nossos interesses". ${ }^{36}$ Vamos a Deus com nossas demandas particulares e imediatas, e ele nos favorece com a revelação do grande desejo, o único desejo que pode saciar nossa sede de plenitude, o desejo que seu reino se instaure em nosso meio. Quando assumimos o despojamento pela oração, renunciamos a nossos próprios interesses, e a palavra (ou mesmo o silêncio) orante se transforma: em vez de pedir que nos satisfaça, pedimos a Deus que nos mostre o que devemos fazer, isto é, em que podemos ajudar para que a vida neste mundo seja melhor.

Etty Hillesum, jovem judia holandesa, considerada uma mística contemporânea, em seu diário forjado em meio aos horrores da segunda guerra mundial, escreveu a respeito da necessidade de ajudar a Deus. Ele só pode nos ajudar se nos dispomos a ajudá-lo. E ajudar a Deus significa para ela, fundamentalmente, proteger o que há de Deus em nós e nos outros. No registro de 12 de julho de 1942, na anotação intitulada "Oração matutina de domingo", lemos:

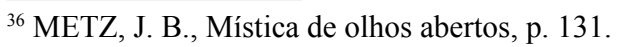


Hei de ajudar-te, Deus, a que não me abandones, mas não posso assegurar nada com antecedência. Mas uma coisa se torna cada vez mais clara para mim: que tu não podes nos ajudar, mas que nós temos de te ajudar e com isso ajudamos a nós mesmos. E essa é a única coisa que podemos salvar nestes tempos e também a única que importa: um pedacinho de ti dentro de nós, Deus. E talvez também possamos ajudar a exumar-te nos corações aflitos de outros. ${ }^{37}$

Enfim, mediante o que foi exposto, reafirmamos que a oração tem poder, que não é o da realização de feitos extraordinários e milagrosos. O poder efetivo da oração - conforme nos ensina a sabedoria bíblica contida no livro de Jó, no S1 23, na experiência de Jesus e na mística de São João da Cruz, assim como nos ensinamentos do Papa Francisco - está na transformação que ela possibilita ao conduzir o fiel ao encontro de Deus - aquele que, para além das imagens dogmatizadas pelas tradições, estabelece conosco uma relação livre. Transformação que promove uma nova forma de ser, de pensar e de querer. Assim, podemos ver que a oração no contexto de uma mística de olhos abertos e pés no chão, mesmo em tempos de pandemia por causa da Covid-19, tem poder porque conduz à saída dos próprios interesses e leva ao compromisso com o outro e com o mundo.

\section{Referências bibliográficas}

BRASIL. Ministério da Saúde. Resposta nacional e internacional de enfrentamento ao novo coronavírus. Disponível em: <https://coronavirus. saude.gov.br/linha-do-tempo/>. Acesso em: 5 fev. 2021.

CHICO BUARQUE. Cálice. G. Gil, C. Buarque [Compositores]. In: CHICO BUARQUE. Chico Buarque. [S.1.]: Polygram/Philips, 1978. 1 LP (ca. 30 min.). Lado A. Faixa 2 (4 min.). Disponível em: <www.chicobuarque.com.br/ construcao/mestre.asp?pg=calice_73.htm>. Acesso em: 5 fev. 2021.

FRANCISCO, PP. Momento extraordinário de oração em tempo de epidemia, 27 mar. 2020. Disponível em: <http://www.vatican.va/content/ francesco/pt/homilies/2020/documents/papa-francesco_20200327_omeliaepidemia.html>. Acesso em: 4 fev. 2021.

GILBERTO GIL. Andar com fé. G. Gil [Compositor]. In: GILBERTO GIL.

${ }^{37}$ HILLESUM, E., Uma vida interrompida, p. 261. 
Um Banda Um. [S.1.]: WEA Discos, 1982. 1 LP (ca. 70 min.). Lado A. Faixa 6 (3 min. 20 s.). Disponível em: <https://gilbertogil.com.br/conteudo/musicas/ pagina/2/>. Acesso em: 19 jan. 2021.

GUTIÉRREZ, G. O Deus da vida. São Paulo: Loyola, 1992.

HILLESUM, E. Uma vida interrompida. Belo Horizonte: Âyiné, 2019.

JOÃO DA CRUZ. Obras Completas. Petrópolis: Vozes, 2000.

KÜNG, H. Projeto de ética mundial: uma moral ecumênica em vista da sobrevivência humana. São Paulo: Paulinas, 2003.

LEGIÃO URBANA. Perfeição. R. Russo, D. Villa-Lobos, M. Bonfá [Compositores]. In: LEGIÃO URBANA. O Descobrimento do Brasil. [S.1]: EMI-Odeon, 1993. 1 LP (ca. 51 min.). Lado A. Faixa 4 (4 min. 37 s.). Disponível em: <http://www.legiaourbana.com.br/descobrimento.html $>$. Acesso em: 24 jan. 2021.

MACKENZIE, R. Fundo cultural e religioso do livro de Jó. Concilium Revista Internacional de Teologia, n. 189, p. 5[1053]-11[1059], 1983.

MESTERS, C. Deus, onde estás? Belo Horizonte: Veja, 1976.

METZ, J. B. Mística de olhos abertos. São Paulo: Paulus, 2013.

MILTON NASCIMENTO. Travessia. F. Brant, M. Nascimento [Compositores]. In: MILTON NASCIMENTO. Travessia (Milton Nascimento). [S.1.]: Codil/Ritmos, 1967. 1 LP (ca. 34 min.) Lado A. Faixa 1 (4 min. 2 s.). Disponível em: <miltonnascimento.com.br/letras.php>. Acesso em: 4 fev. 2021.

MOINGT, J. Deus que vem ao homem: do luto à revelação de Deus. São Paulo: Loyola, 2010.

PAGOLA, J. A. Jesus: uma aproximação histórica. Petrópolis: Vozes, 2010.

PASSOS, J. D. O vírus vira mundo: em pequenas janelas da quarentena. São Paulo: Paulinas, 2020.

PESSINI, L. A espiritualidade interpretada pelas ciências e pela saúde. Mundo da Saúde, v. 31, n. 2, p. 187-195, abr./jun. 2007. Disponível em: $<$ http://www. saocamilo-sp.br/pdf/mundo_saude/53/06_a_espiritualidade.pdf $>$. Acesso em: 3 mar. 2020.

SANTOS, B. S. A cruel pedagogia do vírus. Coimbra: Almedina, 2020.

TEIXEIRA, F. Malhas da hospitalidade. Horizonte - Revista de Estudos 
de Teologia e Ciências da Religião, v. 15, n. 45, p. 18-39, 31 mar. 2017. Disponível em: $<$ http://periodicos.pucminas.br/index.php/horizonte/article/ view/P.2175-5841.2017v15n45p18>. Acesso em: 20 mar. 2020. DOI: https:// doi.org/10.5752/P.2175-5841.2017v15n45p18-39

TRADUÇÃO Ecumênica da Bíblia (TEB). São Paulo: Loyola, 1994.

VELASCO, J. M. A experiência cristã de Deus. São Paulo: Paulinas, 2001.

VIVERET, P. Sobre o bom uso do fim de um mundo. In: SUSIN, L. C; SANTOS, J. M. G. (Orgs.). Nosso planeta, nossa vida: ecologia e teologia. São Paulo: Paulinas, 2011. p. 25-39.

Ceci Maria Costa Baptista Mariani Doutora em Ciência da Religião pela Pontifícia Universidade Católica de São Paulo Docente no Programa de Pós-Graduação em Ciências da Religião da Pontifícia Universidade Católica de Campinas Campinas / RJ - Brasil E-mail: cecibmariani@gmail.com

Breno Martins Campos Doutor em Ciências Sociais pela Pontifícia Universidade Católica de São Paulo Docente no Programa de Pós-Graduação em Ciências da Religião da Pontifícia Universidade Católica de Campinas Campinas / RJ - Brasil E-mail: brenomartinscampos@gmail.com

Recebido em: 09/02/21

Aprovado em: 12/05/21 